\title{
PELAYANAN SYARIAH LINKAJA PADA EKOSISTEM KEISLAMAN DI KOTA CIREBON DALAM PERSPEKTIF HUKUM ISLAM
}

\author{
Afif Muamar, Abdul Aziz, Wasman, dan Nisa Lusiana \\ Institut Agama Islam Negeri Syekh Nurjati Cirebon \\ Email:afifmuamar85@gmail.com,razi_ratnaaziz@yahoo.co.id,wasman1959@gmail.com, \\ dannisalusiana07@gmail.com
}

\begin{abstract}
LinkAja's Sharia Service puts forward three main categories of sharia service products, namely the Zakat, Infaq, Alms and Waqf ecosystems, mosque-based economic empowerment and the digitization of Islamic boarding schools and micro small and medium enterprises. As most of the communities are Muslim, and as there are many religious institutions, Cirebon has become a target for the expansion of LinkAja's Sharia Services. This research used qualitative research methods, the data were collected by interviews, observation, documentation and then were analyzed by descriptive analysis method. The results of this study showed that transactions through LinkAja Sharia Services, especially in Cirebon City, must certainly applied the concept of sharia. The qardh contract is the longest in refilling LinkAja Syariah. LinkAja Syariah services use a qardh contract, namely LinkAja Syariah customers provided by LinkAja Syariah, in this case it is called a top-up and LinkAja Syariah in which it does not use the money, it only saves and it can be returned to the customer at any time in the same form.
\end{abstract}

Keywords: LinkAja Sharia Services, Islamic Ecosystem, and Islamic Law.

\begin{abstract}
Abstrak
Layanan Syariah LinkAja mengedepankan tiga kategori utama produk layanan syariah yaitu ekosistem Zakat, Infak, Sedekah, dan Wakaf, pemberdayaan ekonomi berbasis masjid serta digitalisasi pesantren dan usaha mikro, kecil, dan menengah. Melihat mayoritas masyarakatnya beraga Islam, dan terdapat banyak lembaga keagamaan membuat Kota Cirebon menjadi sasaran perluasan Layanan Syariah LinkAja. Penelitian ini menggunakan metode penelitian kualitatif, data yang dikumpulkan dengan cara wawancara, observasi, dokumentasai kemudian dianalisis dengan metode deskriptif analisis. Adapun hasil dari penelitian ini: Transaksi melalui Layanan Syariah LinkAja khususnya di Kota Cirebon tentu diperbolehkan apabila menggunakan prinsip syariah. Akad qardh adalah yang paling mendekati dalam top-up LinkAja Syariah. Layanan Syariah LinkAja menggunakan akad qardh yaitu customer LinkAja Syariah memberikan kepada pihak LinkAja Syariah dalam hal ini disebut top-up dan pihak LinkAja Syariah tidak mempergunakan uang tersebut, hanya menyimpan dan dapat dikembalikan ke customer kapan saja dalam bentuk yang sama.
\end{abstract}

Kata Kunci: Layanan Syariah LinkAja, Ekosistem Keislaman, dan Hukum Islam. 


\section{PENDAHULUAN}

Dalam era digital saat ini, semakin banyak layanan yang dibentuk dan dikembangkan untuk memudahkan manusia dalam memenuhi kebutuhannya. Lahirnya era digital mengakibatkan pertumbuhan industri digital yang sangat mempengaruhi aktivitas bisnis sehari-hari. Salah satunya adalah sistem pembayaran, dimana penggunaan uang tunai sudah tidak sebanyak dulu. Saat ini uang tidak lagi berbentuk secara fisik, melainkan menjadi sebuah benda tak berwujud yaitu e-money (sistem uang elektronik) (Baihaqi, 2012). E-money merupakan perwujudan dari sistem perbankan modern yang menggunakan alat pembayaran menggunakan kartu atau aplikasi yang sudah terhubung ke rekening bank (Octabriyantiningtyas, Suryani, \& Jatmiko, 2019). Dengan demikian, maraknya transaksi non-tunai pada masa sekarang membuat masyarakat cenderung beralih dari transaksi manual yang menggunakan uang tunai ke transaksi elektronik. Bank Indonesia sendiri bersama dengan instansi terkait pelaku sistem pembayaran Indonesia menyelenggarakan gerakan nasional pada 14 Agustus 2014. Gerakan tersebut dinamakan Gerakan Nasional Non-Tunai (GNNT) yang bertujuan untuk mendorong masyarakat untuk mengurangi transaksi menggunakan uang tunai (cash less society).

Islam memberikan peluang bagi manusia untuk melakukan inovasi terhadap berbagai kebutuhan muamalah yang mereka butuhkan dalam kehidupan mereka, yang didasarkan kepada al-Qur'an dan as-Sunnah, atau atas dasar kaidah-kaidah umum yang berlaku dalam syariat Islam, atau atas dasar hasil ijtihad yang dibenarkan oleh Islam (Haroen, 2007: 8).

Pada pertengahan April 2020 LinkAja meluncurkan fitur baru yaitu layanan berbasis syariah. Layanan Syariah LinkAja mengedepankan 3 (tiga) kategori utama produk layanan syariah yaitu ekosistem ZISWAF (Zakat, Infak, Sodaqoh dan Wakaf), pemberdayaan ekonomi berbasis masjid serta digitalisasi pesantren dan UMKM. Saat ini Layanan Syariah LinkAja telah bekerjasama dengan lebih dari 242 lembaga dan institusi penyaluran ZISWAF, lebih dari 1000 masjid, pesantren serta beberapa mitra e-commerce dan ofline merchant.

Layanan Syariah LinkAja dirancang dengan menggunakan skema syariah melalui akad qardh. Akad qardh adalah akad pinjaman dimana pelanggan menitipkan uangnya kepada Finarya yang merupakan perusahaan yang menaungi LinkAja, dalam bentuk pinjaman. Dalam kegiatan pemenuhan kebutuhan manusia memerlukan adanya batasan agar mereka tidak cenderung untuk menuruti hawa nafsu dan batasan tersebut ialah fiqh muamalah (Muslich, 2013). Muamalah merupakan salah satu bagian dari hukum Islam. Hal ini sesuai dengan pendapat para ahli bahwa hukum muamalah merupakan bagian dari hukum Islam, yaitu hal yang mengatur hubungan antar manusia dalam masyarakat berkenaan dengan kebendaan dan kewajiban (Nawawi, 2012: 9). Muamalah sendiri sering diartikan sebagai suatu aturan hukum Islam untuk mengatur pola akad atau transaksi antar manusia yang berkaitan dengan harta (Mustofa, 2016: 7).

\section{LITERATURE REVIEW}

Dalam era digital saat ini, semakin banyak layanan yang dibentuk dan dikembangkan untuk memudahkan manusia dalam memenuhi kebutuhannya. Lahirnya era digital mengakibatkan pertumbuhan industri digital yang sangat mempengaruhi aktivitas bisnis sehari-hari. Salah satunya adalah sistem pembayaran, dimana penggunaan uang tunai sudah tidak sebanyak dulu. Saat ini uang tidak lagi berbentuk secara fisik, melainkan menjadi sebuah benda tak berwujud yaitu e-money (sistem uang elektronik) (Baihaqi, 2012). E-money merupakan perwujudan dari sistem perbankan modern yang menggunakan alat pembayaran menggunakan kartu atau aplikasi yang sudah terhubung ke rekening bank (Octabriyantiningtyas, Suryani, \& 
Jatmiko, 2019). Dengan demikian, maraknya transaksi non-tunai pada masa sekarang membuat masyarakat cenderung beralih dari transaksi manual yang menggunakan uang tunai ke transaksi elektronik. Bank Indonesia sendiri bersama dengan instansi terkait pelaku sistem pembayaran Indonesia menyelenggarakan gerakan nasional pada 14 Agustus 2014. Gerakan tersebut dinamakan Gerakan Nasional Non-Tunai (GNNT) yang bertujuan untuk mendorong masyarakat untuk mengurangi transaksi menggunakan uang tunai (cash less society).

Islam memberikan peluang bagi manusia untuk melakukan inovasi terhadap berbagai kebutuhan muamalah yang mereka butuhkan dalam kehidupan mereka, yang didasarkan kepada al-Qur'an dan as-Sunnah, atau atas dasar kaidah-kaidah umum yang berlaku dalam syariat Islam, atau atas dasar hasil ijtihad yang dibenarkan oleh Islam (Haroen, 2007: 8).

Pada pertengahan April 2020 LinkAja meluncurkan fitur baru yaitu layanan berbasis syariah. Layanan Syariah LinkAja mengedepankan 3 (tiga) kategori utama produk layanan syariah yaitu ekosistem ZISWAF (Zakat, Infak, Sodaqoh dan Wakaf), pemberdayaan ekonomi berbasis masjid serta digitalisasi pesantren dan UMKM. Saat ini Layanan Syariah LinkAja telah bekerjasama dengan lebih dari 242 lembaga dan institusi penyaluran ZISWAF, lebih dari 1000 masjid, pesantren serta beberapa mitra e-commerce dan ofline merchant.

Layanan Syariah LinkAja dirancang dengan menggunakan skema syariah melalui akad qardh. Akad qardh adalah akad pinjaman dimana pelanggan menitipkan uangnya kepada Finarya yang merupakan perusahaan yang menaungi LinkAja, dalam bentuk pinjaman. Dalam kegiatan pemenuhan kebutuhan manusia memerlukan adanya batasan agar mereka tidak cenderung untuk menuruti hawa nafsu dan batasan tersebut ialah fiqh muamalah (Muslich, 2013). Muamalah merupakan salah satu bagian dari hukum Islam. Hal ini sesuai dengan pendapat para ahli bahwa hukum muamalah merupakan bagian dari hukum Islam, yaitu hal yang mengatur hubungan antar manusia dalam masyarakat berkenaan dengan kebendaan dan kewajiban (Nawawi, 2012: 9). Muamalah sendiri sering diartikan sebagai suatu aturan hukum Islam untuk mengatur pola akad atau transaksi antar manusia yang berkaitan dengan harta (Mustofa, 2016: 7).

\section{METODE PENELITIAN}

Dalam penelitian kualitatif data dikumpulkan dengan dengan beberapa teknik pengumpulan data yaitu wawancara, observasi, dokumentasi dan diskusi terfokus (focus group discussion) (Iryana \& Kawasati, 2011: 3).

Untuk mengumpulkan data-data dari lapangan, metode yang digunakan adalah observasi. wawancara, dokumentasi, dan Focus Group Discussion (FGD).

Kemudian, digunakan pula teknik pengamatan atau observasi adalah akifitas yang dilakukan makhluk cerdas, memahami pengetahuan dari sebuah fenomena berdasarkan pengetahuan dan gagasan yang sudah diketahui sebelumnya untuk mendapatkan informasi-informasi yang dibutuhkan untuk melanjutkan suatu penelitian (Muzani, 1999: 50). Observasi yang dilakukan yaitu dengan mengamati secara langsung praktik dan tinjauan hukum Islam terhadap penggunaan transaksi nontunai melalui Layanan Syariah Linkaja pada ekosistem keislaman.

Selain itu, penelitian ini juga menggunakan interview yang sering disebut dengan wawancara atau kuesioner lisan, adalah sebuah dialog yang dilakukan oleh pewawancara (interviewer) untuk memperoleh informasi dari terwawancara (Arikunto, 2013: 198). Pada praktiknya penulis menyiapkan pertanyaan-pertanyaan untuk diajukan secara langsung salah satu pegawai Kantor Telkomsel Cabang Cirebon untuk mengetahui bagaimana praktik dan tinjauan hukum Islam terhadap penggunaan transaksi non tunai melalui Layanan Syariah 
Linkaja pada ekosistem keislaman di Kota Cirebon.

Penelitian ini juga menganulir data dari dokumentasi, yang merupakan mencari data mengenai hal-hal atau variabel berupa catatan, transkip, buku, surat kabar, majalah, agenda dan sebagainya yang berhubungan transaksi jual beli dengan menggunakan sistem elektronik (Arikunto, 2013: 199). Sebagian besar data yang tersedia adalah berbentuk surat-surat, catatan, laporan, karya tulis dan sebagainya. Secara detail, bahan dokumen terbagi beberapa macam seperti surat-surat pribadi, buku, catatan, klipping, dokumen pemerintah, data yang tersimpan di website, dan lain-lain (Pupu, 2009: 7).

Dan yang terakhir, penelitian ini memperoleh data dari Focus Group Discussion adalah teknik pengumpulan data yang umumnya dilakukan pada penelitian kualitatif dengan tujuan menemukan makna sebuah tema. FGD dimaksudkan untuk menghindari pemaknaan yang salah dari seorang peneliti terhadap fokus masalahyang sedang diteliti. FGD adalah kelompok diskusi, bukan wawancara. Ciri khas metode FGD yang tidak dimiliki oleh metode riset kualitatif lainnya adalah interaksi antara peneliti dengan informan dan informan dengan informan penelitian (Sutopo, 2006: 28).

Selain dengan metode lapangan penelitian ini juga menggunakan metode penelitian kepustakaan (Libarary Research) yaitu penelitian yang dilakukan dengan menggunakan literatur (kepustakaan), baik berupa buku, catatan, maupun laporan hasil penelitian dari penelitian terdahulu. Termasuk hasil penelitian baik yang telah maupun yang belum di publikasikan sebagai pendukung dalam melakukan penelitian, dengan menggunakan berbagai literatur yang ada di perpustakaan yang sesuai dengan masalah yang akan diangkat untuk diteliti.

\section{METODE PENELITIAN}

Jenis penelitian ini adalah kualitatif dengan menggunakan pendekatan yuridis empiris. Penelitian yuridis merupakan penelitian yang melihat hukum sebagai norma atau aturan. Sumber hukum yang digunakan dalam penelitian ini adalah Alquran, Hadis, serta ijma'. Penelitian yuridis adalah hukum sebagai kenyataan sosial ataupun kultural, dimana dalam penelitian ini, peneliti melakukan kajian apa yang terjadi di masyarakat dengan penggunaan media sosial instagram dan aspek hukum dalam Islam tentang aktivitas tersebut.

Penelitian ini disempurnakan dengan kajian literatur yang sudah ada, seperti dari buku serta penelitian-penelitian terdahulu yang mengkaji tentang gharar, penggunaan media sosial maupun muamalah.

\section{KONSEP DASAR}

\section{Layanan Syariah LinkAja}

Terdapat 3 (tiga) perbedaan mendasar pada LinkAja syariah dengan LinkAja konvensional. Pertama, dana mengendap atau floating fund hasil dari saldo yang diisi oleh pelanggan LinkAja Syariah disimpan di bank syariah yang terafiliasi dengan Bank BUKU 4, yaitu bank dengan modal inti di atas Rp. 30 triliun. Namun, bank syariah di dalam negeri belum ada yang memiliki modal inti hingga di atas Rp. 30 triliun. Sehingga, dana yang mengendap disimpan di bank Mandiri Syariah, BNI Syariah, dan BRI Syariah yang terafiliasi dengan Bank BUKU 4. Sedangkan LinkAja konvensional disimpan di bank konvensional.

Kedua, dari segi tata cara transaksi. Diskon atas transaksi yang dilakukan oleh pelanggan LinkAja Syariah harus diberikan oleh pihak merchant, bukan dari LinkAja sebagai fintech sistem pembayaran. Hal tersebut lebih sesuai dengan prinsip syariah.

Dan ketiga, dari segi produknya seperti asuransi dan pinjaman dimana akadnya sesuai dengan akad syariah. Sehingga, untuk LinkAja syariah akan menggandeng partner yang menganut akad pinjaman syariah.

Peluncuran fitur baru Layanan Syariah dapat memudahkan pengguna melakukan transaksi dan penyaluran dana pada ekosistem keislaman khususnya di Kota 
Cirebon. Layanan Syariah LinkAja mengedepankan 3 (tiga) kategori utama produk layanan syariah yaitu ekosistem ZISWAF (Zakat, Infak, Sodaqoh dan Wakaf), pemberdayaan ekonomi berbasis masjid serta digitalisasi pesantren dan UMKM. Penggunaan Layanan Syariah Linkaja antara lain Qurban, Infaq digital pesantren, Infaq masjid, Zakat, Wakaf, dan Top-up saldo dari dan ke Bank Syariah. Fitur lain yang dapat dimanfaatkan pengguna LinkAja Syariah seperti pembayaran iuran sekolah dan pesantren, serta pembayaran di berbagai partner situs belanja.

Layanan Syariah LinkAja dapat dinikmati di seluruh Indonesia melalui ekosistem syariah yang telah dibangun di 88 Kota Madya dan 383 Kabupaten. Dan telah bekerjasama dengan lebih dari 242 lembaga dan institusi penyaluran ZISWAF, lebih dari 1000 masjid, pesantren, online dan offline merchant, serta beberapa mitra e-commerce.

Di Kota Cirebon, Layanan Syariah LinkAja sudah banyak digunakan di bsemua merchant di pusat perbelanjaan seperti Grage Mall, Grage City Mall, CSB, Ramayana Plered, PGC, bebarapa pasar di kota Cirebon seperti Pasar Gunung Sari, Pasar Pagi PGC, dan Pasar Kanoman. Serta dapat digunakan untuk pembayaran zakat di LAZISMU Kabupaten dan Kota Cirebon, pembayaran iuran sekolah/pesantren Kempek, dan penyaluran dana infaq maupun shodaqoh di Masjid at-Taqwa Kota Cirebon.

Penggunaan Layanan Syariah LinkAja di Kota Cirebon memudahkan para pengguna dalam melakukan aktivitas ekonominya. Segala bentuk pembayaran dapat dilakukan dimana pun dan kapan pun tanpa menggunakan uang cash, tetapi hanya dengan scan QRIS dan transfer tanpa biaya admin. Berdasarkan wawancara dengan Jaja sebagai Manager LinkAja Kota Cirebon pada 06 Januari 2021, layanan Syariah di Kota Cirebon berkomitmen akan memperluas mitra dengan semua lembaga penyaluran zakat, pesantren, masjid, dan UMKM di Kota Cirebon untuk mendukung penggunaan uang digital syariah di Indonesia.

\section{Ekosistem Keislaman}

Ekosistem Keislaman merupakan lembaga atau instansi di bidang keislaman yang mengedepankan produk layanan syariah yaitu ekosistem ZISWAF (Zakat, Infaq, Sodaqoh dan Wakaf), pemberdayaan ekonomi berbasis masjid, serta digitalisasi pesantren dan UMKM.

a. Ekosistem ZISWAF

Di era teknologi yang semakin berkembang, transaksi non-tunai memudahkan segala kegiatan manusia. Teknologi yang mendasari transaksi nontunai adalah teknologi internet. Bidang yang diuntungkan dengan adanya internet tentu saja pada sektor jasa salah satunya adalah e-money atau uang elektronik.

Zakat merupakan perwujudan sumber keuangan dari komitmen sosioekonomi yang penting dari umat Islam untuk memenuhi kebutuhan semua orang dengan tidak meletakkan beban ke atas pundak perbendaharaan publik (negara). Zakat yang dilaksanakan sebagai tindak rasional dapat menjamin kepentingan jangka pendek dan jangka panjang (Khasanah, 2010: 49).

Zakat menurut UU No. 38 Tahun 1999 tentang Pengelolaan Zakat, adalah harta yang wajib disisihkan oleh seorang muslim atau badan yang dimiliki orang muslim sesuai dengan ketentuan agama untuk diberikan kepada yang berhak menerimanya (Soemitra, 2010: 48). Sedangkan berdasarkan Kompilasi Hukum Ekonomi Syariah, zakat merupakan harta yang wajib disisihkan oleh seorang muslim untuk diberikan kepada yang berhak menerimanya (Mardani, 2015: 2).

Lembaga atau instansi yang menangani penyaluran dana ZISWAF diantaranya LAZISMU, Zakat Center, LAZ, dan berbagai lembaga lainnya di beberapa kota di Indonesia. Yang bekerjasama membangun ekosistem ekonomi syariah di Indonesia.

b. Pemberdayaan Ekonomi Berbasis Masjid 
Dalam rangka peningkatan ekonomi, sosial, dan transformasi budaya, partisipasi dan pemberdayaan merupakan strategi yang sangat potensial. Yang pada akhirnya dapat menciptakan pembangunan yang berpusat pada masyarakat (Hikmat, 2006: 5).

Untuk mendukung kemudahan pengguna dalam menyalurkan sebagian hartanya, masjid di beberapa kota di Indonesia sudah menggunakan layanan digital. Dengan adanya layanan yang dilakukan secara digital, donasi dan penyaluran dana zakat, infak, sodaqoh dan wakaf ke beberapa masjid dapat dilakukan jarak jauh tanpa mendatangi langsung lembaga terkait.

c. Digitalisasi Pesantren dan UMKM

Pesantren dengan segala potensinya bisa menjadi penggerak perubahan pola hidup dan interaksi ekonomi ke depan. Interkoneksi digital dapat dimanfaatkan untuk menunjang kreativitas dan produktivitas masyarakat, termasuk di lingkungan pesantren.

Kehadiran pesantren modern salah satu bentuk merespon pengembangan sistem pendidikan pesantren pada era digital. Salah satunya pelayanan transaksi non-tunai yang sudah banyak bekerjasama dengan sejumlah sekolah dan pesantren di Indonesia. Dengan adanya layanan tersebut, tentu memudahkan pengguna dalam melakukan pembayaran iuran sekolah dan pesantren secara digital.

Selain itu, ditengah situasi pandemik saat ini sektor UMKM di Indonesia turut berdampak. Dengan adanya layanan digital tentu sangat memudahkan para pelaku UMKM dalam melanjutkan aktivitas ekonomi. Terlebih UMKM kini sudah menjadi kontributor terbesar bagi perekonomian Indonesia, sehingga inisiatif ini diharapkan mampu membantu memulihkan perekonomian negeri, yang manfaatnya bisa dirasakan oleh masyarakat secara luas.

\section{Hukum Islam}

Hukum Islam adalah syariat yang berarti aturan Allah SWT untuk umat-Nya yang dibawa oleh Nabi SAW, baik hukum yang berhubungan dengan kepercayaan (aqidah) maupun hukum-hukum yang berhubungan dengan amaliyah (perbuatan) yang dilakukan oleh semua umat Muslim (Iryani, 2017). Hukum Islam bukan hanya sebuah teori, namun sebuah aturan-aturan untuk diterapkan di dalam sendi kehidupan manusia. Karena banyak ditemui permasalahan-permasalahan, umumnya dalam bidang agama yang sering kali membuat pemikiran umat muslim yang cenderung kepada perbedaan. Untuk itu diperlukan sumber hukum Islam sebagai solusinya, yaitu al-Qur'an, Hadits, Ijma', dan Qiyas.

Sumber hukum Islam yang pertama adalah Al-Qur'an, sebuah kitab suci umat Muslim yang diturunkan kepada nabi terakhir, yaitu Nabi Muhammad SAW melalui Malaikat Jibril. Al-Qur'an memuat kandungan-kandungan yang berisi perintah, larangan, anjuran, kisah Islam, ketentuan, hikmah dan sebagainya. Al-Qur'an menjelaskan secara rinci bagaimana seharusnya manusia menjalani kehidupannya agar tercipta masyarakat yang berakhlak mulia. Maka dari itulah, ayat-ayat al-Qur'an menjadi landasan utama untuk menetapkan suatu syariat.

Sumber hukum Islam yang kedua adalah al-Hadist, yakni segala sesuatu yang berlandaskan pada Rasulullah SAW. Baik berupa perkataan, perilaku, diamnya beliau. Di dalam al-Hadist terkandung aturan-aturan yang merinci segala aturan yang masih global dalam al-Qur'an. Kata hadits yang mengalami perluasan makna sehingga disinonimkan dengan sunnah, maka dapat berarti segala perkataan (sabda), perbuatan, ketetapan maupun persetujuan dari Rasulullah SAW yang dijadikan ketetapan ataupun hukum Islam.

Ijma' merupakan kesepakatan seluruh ulama mujtahid pada satu masa setelah zaman Rasulullah atas sebuah 
perkara dalam agama. Ijma' yang dapat dipertanggung jawabkan adalah yang terjadi di zaman sahabat, tabiin (setelah sahabat), dan tabi'ut tabiin (setelah tabiin). Karena setelah zaman mereka para ulama telah berpencar dan jumlahnya banyak, dan perselisihan semakin banyak, sehingga tak dapat dipastikan bahwa semua ulama telah bersepakat.

Sumber hukum Islam yang keempat setelah al-Quran, al-Hadits dan Ijma' adalah Qiyas. Qiyas berarti menjelaskan sesuatu yang tidak ada dalil nashnya dalam al-Qur'an ataupun hadis dengan cara membandingkan sesuatu yang serupa dengan sesuatu yang hendak diketahui hukumnya tersebut. Artinya jika suatu nash telah menunjukkan hukum mengenai suatu kasus dalam agama Islam dan telah diketahui melalui salah satu metode untuk mengetahui permasalahan hukum tersebut, kemudian ada kasus lainnya yang sama dengan kasus yang ada nashnya itu dalam suatu hal itu juga, maka hukum kasus tersebut disamakan dengan hukum kasus yang ada nashnya.

Tiap sendi-sendi kehidupan manusia, ada tata aturan yang harus ditaati. Bila berada dalam masyarakat maka hukum masyarakat harus dijunjung tinggi. Begitu pula dengan memeluk agama Islam, yaitu agama yang memiliki aturan. Aturan yang pertama kali harus kita pahami adalah aturan Allah (Iryani, 2017: 25).

Hukum Islam membedakan antara ibadah dan muamalah dalam cara pelaksanaan dan perundang-undangan. Ibadah pokok asalnya adalah statis, tidak boleh melampaui apa yang telah disyari'atkan, sedangkan muamalah asal pokoknya adalah merealisasikan kemaslahatan-kemaslahatan dalam pencarian dan kehidupan dan melenyapkan kesulitan mereka dengan menjauhkan perbuatan haram.

Dalam hukum Islam, Fiqh Muamalah diartikan sebagai aturan-aturan (hukum) Allah Swt yang ditujukan untuk mengatur kehidupan manusia dalam urusan keduniaan atau urusan yang berkaitan dengan urusan duniawi dan sosial kemasyarakatan (Syafei, 2001: 15). Fiqh Muamalah telah mengatur prinsip-prinsip yang menjadi dasar untuk bermuamalah, yaitu:

1. Pada dasarnya semua muamalah itu hukumnya mubah, kecuali yang dilarang oleh Al-quran dan sunah rasul. Islam memberi kesempatan luas terhadap perkembangan bentuk dan macam muamalat baru sesuai dengan perkembangan kebutuhan hidup masyarakat.

2. Mumalah dilakukan atas dasar sukarela, tanpa mengandung unsur-unsur paksaan.

3. Muamalah dilakukan atas dasar pertimbangan mendatangkan manfaat dan menghindari mudharat dalam hidup masyarakat.

4. Muamalah dilaksanakan dengan memelihara nilai-nilai keadilan, menghindari unsur-unsur penganiayaan dalam pengambilan kesempatan, dan segala bentuk muamalah yang mengandung unsur penindasan tidak dibenarkan.

Jual beli sebagai bagian dari Muamalah mempunyai dasar hukum yang jelas, baik dari al-Qur'an, al-Sunnah dan telah menjadi ijma' ulama dan kaum muslimin. Bahkan jual beli bukan hanya sekedar muamalah, akan tetapi menjadi salah satu media untuk melakukan kegiatan untuk saling tolong menolong sesama manusia (Siswadi, 2013).

Dalam jual beli terdapat empat macam syarat, yaitu syarat terjadinya akad (in'iqad), syarat sahnya akad, syarat terlaksananya akad (nafadz), dan syarat lujum. Secara umum tujuan adanya semua syarat tersebut antara lain untuk menghindari pertentangan di antara manusia, menjaga kemaslahatan orang yang sedang akad, menghindari jual-beli gharar (terdapat unsur penipuan), dan lain-lain.

Jika jual-beli tidak memenuhi syarat terjadinya akad, akad tersebut batal. Jika tidak memenuhi syarat sah, menurut ulama hanafiyah, akad tersebut fasid. Jika tidak memenuhi syarat nafadz, akad tersebut 
mauquf yang cenderung boleh, bahkan menurut ulama malikiyah, cenderung kepada kebolehan. Jika tidak memenuhi syarat lujum, akad tersebut mukhayyir (pilih-pilih), baik khiyar untuk menetapkan maupun membatalkan (Syafei, 2001: 76).

Sedangkan menurut Mazhab Hanafi rukun jual belinya hanya ijab dan qabul saja. Menurut mereka, yang menjadi rukun jual beli itu hanyalah kerelaan kedua belah pihak untuk berjual beli. Namun karena unsur kerelaan berhubungan dengan hati yang sering tidak keliahatan, maka diperlukan indikator atau alat ukur (Qarinah) yang menunjukkan kerelaan tersebut dari kedua belah pihak (Hasan, 2003: 117).

Rukun dalam jual beli ada tiga, yaitu akad (ijab kabul), orang - orang yang berakad (penjual dan pembeli), dan ma'kud alaih (objek akad). Akad ialah ikatan kata antara penjual dan pembeli. Jual beli belum dikatakan sah sebelum ijab dan kabul dilakukan sebab ijab kabul menunjukkan kerelaan (keridhaan) (Suhendi, 2011: 70).

Kebutuhan manusia dalam bentuk muamalah sangat luas dan berkembang setiap waktu. Maqashid syariah dalam muamalah adalah membolehkan semua bentuk muamalah, selama tidak ada dalil yang mengharamkannya atau melarangnya. Secara bahasa maqashid adalah kata jamak dari maqshad yang berarti "tujuan yang diarahkan semua sarana untuk mencapainya" (Ali, 2007: 13).

Maqashid syariah secara umum adalah makna-makna, atau nilai-nilai dan hikmah-hikmah yang dapat ditangkap dan diperhatikan dan diketahui dari pembuat syariah (Allah). Maqashid syariah adalah ilmu yang membahas tentang tujuan syariah Islamiyah yang ada dalam teks-teks AlQur'an dan Hadits, tujuan dan hikmah yang dapat dilihat dan diketahui oleh manusia, sementara menurut At-Thahir bin Asyur juga temasuk pada tujuan dan hikmah syariah yang tidak dapat diperhatikan, dilihat dan diketahui. Para ulama maqashid sepakat bahwa semua tujuan dan hikmah dari syariah pasti mengandung maslahat bagi hamba di dunia dan akhirat.

Orang-orang yang memahami maqashid syariah akan memandang sebuah kasus atau masalah muamalah dengan hukum boleh, lalu mencari dan memastikan adanya dalil syara' terhadap masalah tersebut, baik dari Al-Qur'an, Sunnah, Ijma' dan Qiyas. Sering terjadi seorang Da'i gegabah memutuskan hukum sebuah perkara muamalat, yang ternyata telah ditetapkan oleh salah satu dari sumber dalil syara' seperti, Ijma' atau Qiyas.

Fatwa atau pandangan dalam muamalah yang memperhatikan maqashid syariah akan mewujudkan moderasi dalam muamalah, karena hukum asli muamalah yang bersifat boleh, akan memberikan keluasan keluesan dan kemudahan dalam hukum muamalah.

Adapun fokus akad yang digunakan adalah akad qardh. Qardh secara bahasa berasal dari kata al-Qath' harta yang dipinjamkan merupakan bagian dari harta milik pihak yang memberi pinjaman. Maksudnya, jadi harta yang di pinjamkan kepada seseorang itu bukan milik orang lain tetapi miliknya sendiri. Al-qardh adalah pemberian harta kepada orang lain yang dapat ditagih atau diminta kembali atau dengan kata lain meminjamkan tanpa mengharapkan imbalan. Dalam literature fiqih klasik, qardh dikategorikan dalam akad tathawwu'i atau akad saling membantu dan bukan transaksi komersil (Antonio, 2001: 131).

Menurut ulama Hanafiah "Qardh adalah harta yang diberikan seseorang dari harta mitsli (yang memiliki perumpamaan) untuk kemudian dibayar atau dikembalikan. Atau dengan ungkapan yang lain, qardh adalah suatu perjanjian yang khusus untuk menyerahkan harta (mal mitsli) kepada orang lain untuk kemudian dikembalikan persis seperti yang diterimanya."

Dari definisi menurut ahli fiqih tersebut Qardh berarti suatu pinjaman harta yang diberikan kepada pihak yang meminjam yang dikemudian hari peminjam itu wajib atau harus mengembalikan harta 
pinjaman tersebut sesuai dengan jumlah harta yang dipinjamnya ketika peminjam sudah mampu untuk membayarnya. Akad Qardh di Indonesia diatur pada Peraturan Bank Indonesia Nomor 7/46/PBI/2015 tentang Qardh diartikan sebagai pinjam meminjam dana tanpa imbalan dengan kewajiban pihak peminjam mengembalikan pokok pinjaman secara sekaligus atau cicilan dalam waktu tertentu (Usanti, 2016: 72).

Menurut Kompilasi Hukum Ekonomi Syari'ah (KHES) Qardh adalah penyediaan dana atau tagihan antar lembaga keuangan syari'ah dengan pihak peminjam yang mewajibkan pihak peminjam untuk melakukan pembayaran secara tunai atau cicilan dalam jangka waktu tertentu. Menurut Fatwa DSN No. 19/DSNMUI/IV/2001, AlQardh adalah pinjaman yang diberikan kepada nasabah (muqtaridh) yang memerlukan. Nasabah Al-Qardh wajib mengembalikan jumlah pokok yang diterima pada waktu yang telah disepakati bersama. Dari beberapa definisi di atas dapat disimpulkan bahwa akad Qardh pada hakikatnya adalah bentuk pertolongan dan kasih sayang bagi yang meminjam, bukan suatu sarana untuk mencari keuntungan bagi yang memijamkan, di dalamnya tidak ada imbalan dan kelebihan pengembalian. Namun dalam Qardh ini mengandung nilai kemanusiaan dan sosial dimana dalam akad ini peminjam tidak boleh mensyaratkan keuntungan dalam pinjaman dan ia boleh menerima lebih jika peminjam memberikannya dalam jumlah yang lebih selama tidak dipersyaratkan di awal dan tidak diperjanjikan.

Rukun Qardh menurut ulama Hanafiyah adalah ijab dan kabul. Sementara menurut Jumhur ulama rukun Qardh ada tiga, yaitu:

1. Dua orang yang berakad yang terdiri dari muqridh (yang memberikan utang) dan muqtaridh (orang yang berutang).

2. Qardh (barang atau objek yang dipinjamkan)

3. Shigat ijab dan kabul.

Dengan demikian, syarat sahnya diperbolehkan untuk melakukan Qardh memang harus ada keseluruhan rukun tersebut. Jika salah satunya tidak ada, maka peminjaman tersebut dinyatakan tidak sah secara hukum islam. Ijab dan kabul dalam Qardh sama seperti ijab kabul dalam jualbeli. Ijab dan kabul dalam Qardh, merupakan ucapan yang disampaikan langsung oleh peminjam kepada penerima pinjaman bahwa peminjam mengijinkan secara langsung uang tersebut dipinjam. Keduanya saling ridha terhadap akad tersebut. Ketentuan dan syarat harta qardh dari segi kepemilikan berlaku ketentuan dan syarat al-mabi' (benda yang diperjualbelikan), yaitu harta yang diqardhkan harus milik muqridh karena sifat altamlik-nya sama, yaitu harta Qardh berpindah kepemilikannya dari milik muqridh menjadi milik muqtaridh sehingga muqridh harus memiliki hak untuk memindahkan kepemilikan barang yang di qardh-kan. Harta yang boleh dijadikan objek akad Qardh harus harta yang miliknya yang disepakati ukurannya, baik secara kuantitas maupun kualitasnya. Personalia akad (muqridh) harus termasuk pihak yang memiliki kemampuan untuk melakukan tabarru' karena akad qardh termasuk akad yang menyebabkan terjadinya perpindahan kepemilikan objek tanpa disertai imbalan. Tidak boleh mengambil manfaat dari akad ini meskipun sudah disetujui oleh kedua belah pihak (Sjahdeini \& Remy, 1999: 41).

\section{PEMBAHASAN DAN DISKUSI}

LinkAja merupakan platform keuangan digital sinergi BUMN dari berbagai sektor, mulai dari perbankan, telekomunikasi, energi, asuransi, hingga transportasi seperti Telkomsel, Jasamarga, bank BNI, BRI, Mandiri, PT. Kereta Api Indonesia (KAI), Pertamina, Taspen dan lainnya.

LinkAja berfokus pada segmen pasar unbanked/underbanked melalui channel penjualan yang luas serta kerjasama dengan Pemdes setempat. Dengan tujuan mendorong inklusi keuangan dan inklusi ekonomi untuk meningkatkan pertumbuhan ekonomi 
nasional Indonesia.

Masterplan Ekonomi Syariah Indonesia tahun 2019-2024 yaitu "Menjadikan Indonesia yang Mandiri, Makmur, dan Madani dengan menjadi Pusat Ekonomi Syariah Terkemuka di dunia", perlu adanya uang elektronik syariah sebagai sistem pembayaran. Untuk mewujudkan masterplan tersebut, pada Februari 2020 PT. Fintek Karya Nusantara (FINARYA) sebagai penerbit uang elektronik LinkAja mendapat Sertifikat Kesesuaian dengan Prinsip Syariah DSN MUI No.116/DSN-MUI/IX/2017 tentang uang elektronik syariah serta izin pengembangan produk uang elektronik server-based dari Bank Indonesia.

LinkAja Syariah merupakan uang elektronik syariah pertama di Indonesia yang memfasilitasi berbagai jenis pembayaran sesuai kaidah syariah. Kehadiran LinkAja Syariah juga sebagai jawaban atas kebutuhan masyarakat di era digital untuk melakukan transaksi dengan mudah, cepat aman dan sesuai kaidah syariah.

Penggunaan Layanan Syariah LinkAja di Kota Cirebon sampai saat ini terus meningkat, terlihat dari antusias masyarakat dan berbagai pihak serta lembaga dan institusi yang semakin banyak beralih ke Layanan Syariah LinkAja dalam melakukan aktivitas transaksinya.

Peneliti telah melakukan wawancara mengenai kepuasan terhadap Layanan Syariah LinkAja dengan Nova yang merupakan salah satu pengguna Layanan Syariah LinkAja. Dengan berbagai kemudahan yang diberikan oleh Layanan Syariah LinkAja, membuat Nova sebagai pengguna merasa efektif dan efisien ketika melakukan transaksi. Nova juga mengatakan bahwa dia merasa aman ketika bertransaksi menggunakan uang elektronik Layanan Syariah LinkAja, karena dia mengetahui betul bahwa uang dalam LinkAja Syariah tersimpan di Bank Syariah Indonesia (BSI) sehingga tidak tercampur dengan dana yang ada di bank konvensional. Berdasarkan wawancara dengan Nova sebagai pengguna layanan syariah LinkAja pada 06 Februari
2021, ia merasa senang walaupun ketika melakukan pembelian, pihak LinkAja Syariah tidak memberikan potongan harga atau discount karena tidak sesuai dengan akad dan prinsip syariah. Melakukan transfer ke rekening bank pun tidak ada tambahan administrasi. Sehingga para pengguna sejauh ini merasa puas dengan Layanan Syariah LinkAja.

Pada saat wawancara dengan Ari selaku Pelayanan di LAZISMU Kabupaten Cirebon dia mengatakan bahwa semenjak bergabung menjadi mitra Layanan Syariah LinkAja pada 20 Juli 2020, penyaluran dana zakat, infaq, maupun shodaqoh mengalami peningkatan. Karena menurutnya dengan adanya Layanan Syariah LinkAja dapat mempermudah muzakki untuk membayar zakat. Ari juga mengatakan sebelum bekerjasama dengan Layanan Syariah LinkAja pihaknya melakukan crosscheck atau pemeriksaan kembali karena dikhawatirkan dalam praktiknya tidak sesuai dengan kaidah syariah. Setelah melakukan crosscheck akhirnya LAZISMU tertarik untuk bekerjasama dengan Layanan Syariah LinkAja. Salah satu alasannya adalah karena dalam transaksinya uang yang terhimpun dari para donatur disimpan di Bank Syariah Indonesia, bukan di bank konvensional sehingga pihak LAZISMU merasa aman dalam melakukan aktivitas transaksinya. Berdasarkan wawancara dengan Ari sebagai Pelayanan LAZISMU Kabupaten Cirebon pada 19 Januari 2021, pihak LAZISMU juga meyakini bahwa Layanan Syariah LinkAja sudah sesuai dengan prinsip syariah sehingga tidak ada unsur riba didalamnya.

Namun, setelah peneliti melakukan observasi secara langsung masih banyak masyarakat khususnya di Kota Cirebon yang tidak mau menggunakan Layanan Syariah LinkAja karena tidak ada diskon yang diberikan oleh pihak LinkAja. diskon hanya didapat apabila merchant yang bekerjasama dengan LinkAja memberikan potongan harga.

Selain itu juga banyak pengguna Layanan Syariah LinkAja yang belum 
memahami fitur yang ada di dalam aplikasi sehingga mereka jarang menggunakan Layanan Syariah LinkAja untuk aktivitas transaksinya walaupun mereka memiliki aplikasi tersebut. Dengan adanya Layanan Syariah LinkAja diharapkan dapat memudahkan masyarakat Indonesia khususnya umat muslim untuk bertransaksi dalam berbagai kegiatan ekonomi.

Teknologi adalah segala daya upaya yang dapat dilaksanakan oleh manusia untuk mendapat taraf hidup yang lebih baik. Teknologi juga merupakan faktor pendorong dari fungsi produksi, dapat dikatakan demikian karena jika suatu teknologi yang digunakan lebih modern maka hasil produksi yang akan tercapai akan menghasilkan barang atau jasa yang lebih banyak dan lebih efisien atau efektif (Muttaqin, 2004, hal. 19). Begitu pula dengan Layanan Syariah LinkAja, sebuah aplikasi hasil dari kemajuan teknologi yaitu uang elektronik yang digunakan sebagai alat pembayaran nontunai yang memudahkan manusia melakukan aktivitas transaksi yang sesuai dengan prinsip syariah.

Islam tidak melarang bentuk teknologi selagi tidak bertentangan dengan ajarannya. Al-Quran malah memberitakan bahawa manusia adalah khalifah di atas muka bumi dan Allah menempatkan posisi alam ini untuk digunakan oleh manusia dengan usaha-usahanya yang baik. Menurut al-Syatibi sebagaimana dikutip oleh Bakri, mengatakan bahwa "sesungguhnya syariat itu bertujuan mewujudkan kemaslahatan manusia di dunia dan di akhirat". Dan dalam ungkapan yang lain, dikatakan oleh alSyatibi yang artinya "Hukum hukum disyariatkan untuk kemaslahatan hamba." (Bakri, 1996: 62). Apabila ditelaah pernyataan Al-Syatibi tersebut, dapat dikatakan bahwa kandungan Maqasid Syariah atau tujuan hukum adalah untuk kemaslahatan ummat manusia. Tidak ada satupun hukum Allah dalam pandangan alSyatibi yang tidak mempunyai tujuan (Bakri, 1996: 63). Pernyataan tersebut menegaskan bahwa kemaslahatan merupakan tujuan atau hasil yang diraih oleh Maqasid Syariah.

Prinsip syariah adalah prinsip hukum Islam dalam kegiatan muamalah (interaksi sesama manusia) yang mendorong kepada hal-hal kebaikan ( $m a^{\prime}$ ruf) dan mencegah dari hal-hal buruk yang diharamkan oleh syariah (munkar). Sedangkan menurut UU No 21 Tahun 2008 tentang perbankan syariah prinsip syariah adalah prinsip hukum Islam dalam kegiatan perbankan berdasarkan fatwa yang dikeluarkan oleh lembaga yang memiliki kewenangan dalam penetapan fatwa di bidang syariah. Secara umum prinsip syariah terbagi menjadi 2 yaitu prinsip syariah dalam hal ibadah dan prinsip syariah dalam bidang muamalah (interaksi antara manusia). Prinsip syariah dalam bidang muamalah adalah:

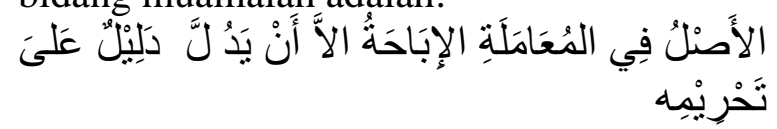

Maksud prinsip ini adalah bahwa dalam setiap muamalah dan transaksi, pada dasarnya boleh, seperti jual beli, sewa menyewa, gadai, kerja sama (mudharabah dan Musyarakah), perwakilan, dan lain-lain. Kecuali yang tegas-tegas diharamkan seperti mengakibatkan kemudaratan, tipuan, judi, dan riba. Dalam transaksi melalui Layanan Syariah LinkAja khususnya di Kota Cirebon tentu diperbolehkan apabila menggunakan prinsip Syariah.

Pada saat customer melakukan top-up ke LinkAja, sama sekali tidak ada akad. Yang ada hanya niat melakukan akad. Sehingga uang top-up statusnya adalah utang dari customer ke LinkAja. LinkAja Syariah jika Qardh itu utang, berarti pihak customer tidak boleh menerima keuntungan apapun dari pihak LinkAja. Tetapi disini Layanan Syariah LinkAja tidak memberikan diskon bagi penggunanya yang membayar via Layanan Syariah LinkAja karena tidak sesuai dengan akad yang digunakan, namun diskon hanya diberikan oleh merchant atau toko yang bekerjasama dengan Layanan Syariah LinkAja kepada customer nya. Dalam Hadits Riwayat Baihaqi dalam As-Shugra sebagaimana dikutip oleh Yazid Affandi, 
Ubaid mengatakan: "Semua utang yang menghasilkan manfaat statusnya riba.."

Ulama Fiqh sepakat bahwa qardh dikategorikan sebagai akad Tathawwu'i (akad saling tolong menolong), bukan transaksi komersil. Maka, dalam perbankan syariah akad ini dapat digunakan untuk menjalankan kegiatan sosial bank syariah. Yaitu dengan memberi pinjaman murni kepada orang yang membutuhkan tanpa dikenakan apapun. Meskipun demikian nasabah tetap berkewajiban untuk mengembalikan dana tersebut, kecuali jika bank mengikhlaskannya. Jika dengan pinjaman ini nasabah berinisiatif untuk mengembalikan lebih dari pinjaman pokok, bank sah untuk menerima, selama kelebihan tersebut tidak diperjanjikan di depan.

Akan jauh lebih efektif jika pinjaman yang diberikan adalah dipergunakan untuk kepentingan produktif, bukan untuk konsumtif. Adapun cara pengembaliannya dengan cara diangsur, maupun dibayar sekaligus. Jika pinjaman sudah dikembalikan, bank dapat memutar kembali secara bergulir.

Dalam kasus transaksi melalui Layanan Syariah LinkAja, uang customer tersimpan di Bank Syariah, bukan di Bank Konvensional sehingga dana yang tersimpan aman tidak tercampur dengan dana yang ada di Bank Konvensional. Dan khusus pengguna layanan uang elektronik LinkAja Syariah yang membayar dengan LinkAja Syariah dalam transaksi pembelian makanan, belanja, pembayaran zakat atau pun aktivitas transaksi lainnya hanya akan mendapat potongan harga apabila merchant atau toko yang sudah menjadi mitra LinkAja Syariah memberikan potongan harga. Tetapi, customer tidak akan mendapat potongan harga dari pihak LinkAja karena merupakan riba dan tidak sesuai dengan akad yang digunakan dalam Layanan Syariah LinkAja.

\section{KESIMPULAN}

Penggunaan Layanan Syariah LinkAja di Kota Cirebon sampai saat ini terus meningkat, terlihat dari antusias masyarakat dan berbagai pihak serta lembaga dan institusi yang semakin banyak beralih ke Layanan Syariah LinkAja dalam melakukan aktivitas transaksinya.

Dengan berbagai kemudahan yang diberikan oleh Layanan Syariah LinkAja, membuat para pengguna merasa efektif dan efisien ketika melakukan transaksi. Begitu juga dengan LAZISMU Kabupaten Cirebon sebaagai lembaga penyaluran zakat, infaq dan shodaqoh, mereka merasa aman dengan adanya Layanan Syariah LinkAja karena dalam transaksinya uang yang terhimpun dari para donatur disimpan di Bank Syariah Indonesia, bukan di bank konvensional sehingga pihak LAZISMU merasa aman dalam melakukan aktivitas transaksinya. Pihak LAZISMU Kabupaten Cirebon juga meyakini bahwa Layanan Syariah LinkAja sudah sesuai dengan prinsip syariah sehingga tidak ada unsur riba didalamnya.

Transaksi melalui Layanan Syariah LinkAja khususnya di Kota Cirebon tentu diperbolehkan apabila menggunakan prinsip syariah. Akad qardh adalah yang paling mendekati dalam top-up LinkAja Syariah. Pada saat customer melakukan top-up ke LinkAja, sama sekali tidak ada akad. Yang ada hanya niat melakukan akad. Sehingga uang top-up statusnya adalah utang dari customer ke LinkAja. Layanan Syariah LinkAja menggunakan akad qardh yaitu customer LinkAja Syariah memberikan kepada pihak LinkAja Syariah dalam hal ini disebut top-up dan pihak LinkAja Syariah tidak mempergunakan uang tersebut, hanya menyimpan dan dapat dikembalikan ke customer kapan saja dalam bentuk yang sama.

Dalam kasus transaksi melalui Layanan Syariah LinkAja, uang customer tersimpan di Bank Syariah Indonesia, bukan di Bank Konvensional sehingga dana yang tersimpan aman tidak tercampur dengan dana yang ada di Bank Konvensional. Dan khusus pengguna layanan uang elektronik LinkAja Syariah yang membayar dengan LinkAja Syariah tidak akan mendapat potongan harga dari pihak LinkAja karena merupakan riba 
dan tidak sesuai dengan akad yang digunakan dalam Layanan Syariah LinkAja.

\section{DAFTAR PUSTAKA}

Ali, M. A. A. M. (2007). Al-Maqashid AsSyar'iyah Watsaruha Fil Fiqhil Islami. Kairo: Darul Hadits.

Antonio, M. S. (2001). Bank Syariah. Jakarta: Gema Insani.

Arikunto, S. (2013). Prosedur Penelitian Suatu Pendekatan Praktik. Jakarta: Reneka Cipta.

Baihaqi, A. (2012). Analisis Penerimaan Pengguna "Telkomsel Cash" Terhadap Sistem Pembayaran Elektronik Menggunakan Technology Acceptance Model (TAM). Universitas Gunadarma

Bakri, A. J. (1996). Konsep Maqasid Syar'ah menurut Al-Syatibi. Jakarta, Indonesia: Raja Grafindo Persada.

Haroen, N. (2007). Fiqh Muamalah, Cet. Ke2. Jakarta: Gaya Media Pertama.

Hasan, A. (2003). Masa 'il fikhiyah. Jakarta: PT. Raja Grafindo.

Hikmat, H. (2006). Strategi Pemberdayaan Masyarakat. Bandung: Humaniora Utama Press

Iryana \& Kawasati, R. (2011). Teknik Pengumpulan Data Metode Kualitatif. STAIN Sorong. Diakses dari https://osf.io/cy9de/download/?format $=$ pdf.

Iryani, E. (2017). Hukum Islam, Demokrasi dan Hak Asasi Manusia. Jurnal Ilmiah Universitas Batanghari Jambi, 17(2), 24-31.

Khasanah, U. (2010). Manajemen Zakat Modern. Malang: UIN Maliki Press.

Mardani. (2015). Aspek Hukum Lembaga Keuangan Syariah Di Indonesia. Jakarta: Prenada Media.

Muslich, A. W. (2013). Fiqh Muamalat, Cetakan ke 2. Jakarta: Amzah.

Mustofa, I. (2016). Fiqh Muamalah Kontemporer. Jakarta: Raja Grafindo.

Muttaqin, Z. (2004). Manajemen Teknologi Agribisnis. Jakarta: Ghalia Indonesia.

Muzani, A. (1999). Metode Observasi.
Surabaya: PT. Graha Pustaka Indonesia.

Nawawi, I. (2012). Fikih Muamalah Klasik dan Kontemporer. Bogor: Ghalia Indonesia.

Octabriyantiningtyas, D., Suryani, E., \& Jatmiko, A. R. (2019). Modeling customer satisfaction with the service quality of e-money in increasing profit of PT. Telekomunikasi Indonesia. Procedia Computer Science, 161, 943-950.

Pamungkas, S. (2018). Pengaruh Kepercayaan, Kegunaan dan Kemudahan Terhadap Minat Menggunakan Mobile Money T-Cash Pada Mahasiswa Jurusan Perbankan Syariah IAIN Surakarta. Skripsi, Fakultas Ekonomi dan Bisnis IAIN Surakarta.

Pupu, S. R. (2009). Penelitian Kualitatif. Jurnal Eqiulibrum, 5(9).

Sjahdeini \& Remy. (1999). Perbankan Islam dan Kedudukannya dalam Tata Hukum Perbankan Indonesia. Jakarta: PT. Pustaka Utama Grafiti.

Siswadi. (2013). Jual Beli dalam Perspektif Hukum Islam. Ummul Qura, 3(2).

Soemitra, A. (2010). Bank dan Lembaga Keuangan Syariah. Jakarta: Kencana Prenada Media Group.

Suhendi, H. (2011). Fiqih Muamalah. Jakarta: Raja Grafindo Persada.

Sutopo. (2006). Metodologi Penelitian Kualitatif. Surakarta: Sebelas Maret Press.

Syafei, R. (2001). Fiqih Muamalah. Bandung: Pustaka Setia.

Usanti, T. P. (2016). Hukum Perbankan. Jakarta: Kencana Prenandamedia Grup.

Wibowo, A. (2018). Transaksi Pembayaran T-Cash dengan Dukungan Teknologi Berbasis Near Field Communications (NFC). Applied Information System and Management (AISM), 1(1). 